Vol. 6, Issue 2, February 2019

\title{
Critical Success Factors of Total Quality Management in Software Development
}

\author{
Bodor Moheel $^{1}$, Safaa Alkatheri ${ }^{2}$, Afnan AISukhayri ${ }^{3,}$ Azrilah AbdulAziz ${ }^{4}$ \\ Student, Information System Department, Faculty of Computing \& Information Technology, \\ King Abdulaziz University, Jeddah, Saudi Arabia ${ }^{1,2,3}$ \\ PhD, Information System Department, Faculty of Computing \& Information Technology, King Abdulaziz University, \\ Jeddah, Saudi Arabia ${ }^{4}$
}

\begin{abstract}
Due to the considerable competition and fast growth in the software industry, software development has become essential. Thus, software quality is a vital instrument in software development field as well as in the determination of the most important Critical Success Factors (CSFs) in software development. The theory of Total Quality Management (TQM) adopted by organizations to achieve quality and improved organizations' performance while meeting and exceeding customers' expectations. This paper discusses the CSFs that can be applied to software development to implement the TQM for the software development field. The result presented the impact of the progress in time and technology on the rank of the essential CSFs while discovering the new CSFs that did not exist before.
\end{abstract}

Keywords: Critical success factor, System development, Software quality, Total quality management.

\section{INTRODUCTION}

The quality of software is becoming a principal instrument in software development field. Academics and researchers see it as one of the most critical issues of the 1990s [1, 2]. The emphasis on software quality arises for many reasons. The first reason is, historically, information systems have poor quality software which leads to producing different software that does not meet the benefits or expectations of the users. The second reason is related to the pervasiveness of information technology, which has increased the demand for high-quality software. As well as, the safety requirements for some software have led to this pressure for quality. All these reasons have led to the focus on high priority critical Success Factors (CSFs) in software development. One of the most important things that lead to achieving high quality within any organization is the theory of Total Quality Management (TQM). This theory was generated initially in the manufacturing sector and later applied to other sectors.

Many literature reviews discuss the CSFs of TQM in software development and reveal that there is a poor understanding of implementing them. They are also advocating that the application of TQM in software development based on a limited understanding of the CSFs of TQM. It also involves how they used to achieve software quality without studying the impact of time and technology on the ranking of those factors through disappearing some of them or even creating new factors [3]. This paper explains the most critical CSFs that can be applied to software development to implement the TQM for the software development sector. Each of the CSFs of TQM is explained and analyzed in relation to software development differences over the time.

The rest of the paper has been organized in the following way. The second section explains the concept of TQM and its benefits from the organization's' perspective. The third section presents the role of TQM in software development and how it impacts on software quality. Section four explains the problem definition and the main objective of this paper. Section fifth is concerned with the methodology used for this study. Section six presents a comprehensive study of CSFs of TQM in software development based on ten research papers. The seventh section presents the findings of the research and gives some explanations for those findings. The last section concludes the paper and presents some future works.

\section{TQM CONCEPTS AND BENEFITS}

Total Quality Management (TQM) is a management and quality approach that guarantees the sustainable improvement in the organization while meeting and exceeding customers' expectations [4]. It integrates the management and quality tools that aim to improve businesses [5]. It includes a multi-disciplinary approach such as statistics to improve 


\title{
International Advanced Research Journal in Science, Engineering and Technology
}

\author{
Vol. 6, Issue 2, February 2019
}

processes, and managerial skills to improve the human components of production and customer relations focus to deliver the product the customer wants [1]. Several dimensions shape TQM such as top management support, customer and supplier relationship and employee involvement [6]. TQM is considered as a long-term strategy rather than shortterm strategy [1]. Thus, quality can be achieved through continuous improvement of all activities of the organization and requires extreme changes in an organization's culture [1]. There are several benefits of implementing TQM in the organization:

- The growth, stability, and prosperity of business [7].

- Practices that ensure top management commitment, satisfying customer needs internally and externally, continuous improvement, employee involvement and teamwork, and employee empowerment to make their own decisions [7, 8].

- The enhancement of the competitive performance by improving the quality of processes, products, services, people, and organization's culture [1].

- Problem-solving and future prediction [8].

\section{TQM, SOFTWARE DEVELOPMENT, AND SOFTWARE QUALITY}

\section{A. Software Development}

Software Development became important due to extensive competition in the software industry [9]. The system development life cycle combines the steps of planning, analysis, design, implementation, and support [10]. There are several tools and development techniques used for software quality and user satisfaction [11]. These development techniques include object-oriented analysis, system development life cycle (SDLC), computer-aided software engineering, and prototyping [11].

\section{B. TQM in Software Development}

The information system (IS) functions have a significant role in the TQM initiative through the human resources, strategic, and technology areas [6]. TQM represents a complete change in the definition of quality in product development [10]. Many software development organizations that use TQM philosophy to improve the software quality and their developmental efficiencies [7]. The primary attribute of software development is the quality which determines the user's satisfaction [9]. The activities of software development have to be done cautiously to produce high-quality software that meets the customer's primary needs [9]. Therefore, it is mandatory to include TQM in the development process to ensure the acceptance of the user [9]. The TQM implementation is aimed to improve quality to enhance efficiency, effectiveness and to achieve a high level of development [8]. In the development process, the crossfunctional orientation and teamwork are essential to integrate many different parts of the organization [10].

\section{TQM and Software Quality}

The software quality is vital due to some reasons [1]. First, in the past, information system (IS) was observed to have poor quality software which failed to meet the user's needs [1]. Second, the spread of information technology (IT) in organization increase the pressure for the high-quality system [1]. However, implementing software quality requires much effort, financial resources and time [7]. The software quality assurance is not enough to assure software quality [10]. However, the TQM methods must apply to the entire software development not just development processes [10]. TQM provides a framework to achieve the software quality where the customer's quality needs are specified and met by the software developers [1]. Thus, software quality assurance provides a methodology to assure quality while software TQM provides a framework to improve it continually [10].

Therefore, software quality can be qualified and identified by a set of attributes such as maintainability, reliability, usability, portability, integration, consistency, salability, functionality, efficiency, and extensibility [9]. These attributes are used to measure the extent to which the software meets the client's expectations and solves the problems [9]. In the software application, the time, performance, usability, and acceptability are a critical element of quality [9]. The timesaving and performance benefits offered through faster and more dynamic processing of data [9].

Teamwork relies on sharing the information with team members which encourages them to work harder to achieve the organizational goals [10]. The team members capabilities, development team skills, and tools also used to affect the quality of the software [7]. The development team should follow the TQM specific methods to customize a high-quality software to compete in the software industry [9]. The specific method used in software development depends on the 


\title{
International Advanced Research Journal in Science, Engineering and Technology
}

\author{
Vol. 6, Issue 2, February 2019
}

implementation method and the nature of the desired product [9]. This method or tool enhances quality by combining all its elements, which are required by the philosophy of TQM [9].

\section{Problem DEFINITION}

Many challenges that arise within the software industry is a result of rapid global competition and technological evolution of many businesses which include startups [7]. Therefore, the solution to this problem is to satisfy the growing and varying needs of customers. TQM philosophy which is adopted by many organizations makes "quality" a priority through customer satisfaction, teamwork, and continuous improvement $[12,13]$.

Some researchers acknowledge the relationship between adopting TQM and improved organization's performance [14, 15], quality performance[16], long-term profitability [17, 18], and positively related to innovation performance [19]. This is solely because they agree that the concept of TQM can improve all these different areas. It would also be vital to consider such philosophy to improve developmental efficiencies and enhance the quality of software [11, 20]. There are only a few research on implementing TQM in software development such as [7], but are not comprehensive and differ in identifying the most important critical factors to implement TQM in software development. Therefore, this study attempts to discover the factors of TQM in software development through research papers.

\section{METHODOLOGY}

Research methodology is essential to guide all researchers about all the steps needed to accomplish the primary objective of the research. The purpose of this research paper is to determine the factors that contribute to the success of TQM in software development. The content analyses have been used to create a summary of the most CSFs. In this research, we provide a review of CSFs of TQM in software development articles published between 1989 -2017. The search was limited to 15 keywords that used to describe CSFs of TQM in software development. The lists of search keywords are listed below:

- Total quality management

- Software process improvement

- Continuous process improvement

- Total quality

- Dimensions

- Critical factors

- Quality Management

- Quality control information system

- Information technology

- Information system

- Information system management

- $\quad$ ISO 9001:2000

- System development

- $\quad$ Software quality

- Business performance

\section{CRITICAL SUCCESS FACTORS (CSFS) OF TQM IN SOFTWARE DEVELOPMENT}

CSFs of TQM in the software development in Table 1 are based on the findings of a literature survey on research papers. Table 2 shows the comparative studies of research papers. 


\section{International Advanced Research Journal in Science, Engineering and Technology}

Vol. 6, Issue 2, February 2019

Table 1 Factors to Implement TQM in the Software Development

\begin{tabular}{|c|c|}
\hline CSFs & Description \\
\hline $\begin{array}{l}\text { Top-Management } \\
\text { Commitment and } \\
\text { Leadership }\end{array}$ & $\begin{array}{l}\text { Top-management Commitment and Leadership remains an essential factor for the successful } \\
\text { implementation of TQM. Also, quality improvement methods will need to begin from the top } \\
\text { to lower levels. Organisational quality initiatives, policies and goals, and strategic plans } \\
\text { through quality mission statements are only achieved via Top-management commitment [5- } \\
8,10,11,13,21-23] \text {. }\end{array}$ \\
\hline $\begin{array}{c}\text { Client } \backslash \text { Customer } \\
\text { Focus }\end{array}$ & $\begin{array}{l}\text { In this aspect, it is vital that the needs or requirements of customers are identified, and levels } \\
\text { of satisfaction derived from the product or service are measured on a scale regularly. Hence, } \\
\text { the TQM concept is highly dependent on the level of satisfaction a customer derives from a } \\
\text { product. Clients should be involved in the process product Iservice design, feedback, and also } \\
\text { communication channels }[5-8,21-23] \text {. }\end{array}$ \\
\hline $\begin{array}{l}\text { Organizational } \\
\text { Culture }\end{array}$ & $\begin{array}{l}\text { Organizational culture needs to change or be modified for an effective TQM implementation. } \\
\text { Team players within an organisation need to have a common perception that quality is } \\
\text { always a priority while every member of the team understands his or her responsibilities. A } \\
\text { flexible organisation with coordination, incentives and so on to boost and produce brilliant } \\
\text { results }[7,8,10,22] \text {. }\end{array}$ \\
\hline $\begin{array}{c}\text { Process Quality } \\
\text { Management }\end{array}$ & $\begin{array}{l}\text { During the process of software development, each employee plays a vital role in the } \\
\text { achievement of each task. Hence, it is paramount that each employee aims for quality as the } \\
\text { focal point of every product. Process documentation, monitoring and assessment will result } \\
\text { in excellent quality and minimal errors }[5-7,10,11,13,22,23] \text {. }\end{array}$ \\
\hline $\begin{array}{l}\text { Quality Measures } \\
\text { (Metrics) }\end{array}$ & $\begin{array}{l}\text { Data measurement and analysis constitute a significant part of TQM. Quality of products, } \\
\text { techniques, and tools are all evaluated using metrics. Metrics also takes into consideration } \\
\text { quality performance like defects and effort. It also allows the development team to keep up } \\
\text { with efficient development processes. For TQM to be effectively implemented, the following } \\
\text { have to be measured: defect density, project cost, process improvement, and assessment of } \\
\text { effort and project. Statistical tools and charts can be used to measure [7, 10,11, 13, 22, 23]. }\end{array}$ \\
\hline $\begin{array}{l}\text { Human Resource } \\
\text { Management }\end{array}$ & $\begin{array}{l}\text { Skilled personnel are often required to fill positions in software development organisations. } \\
\text { This personnel to be treated with maximum care and as valuable assets. They must also be } \\
\text { trained regularly to be aware of currents globally. Employees should also be assessed based } \\
\text { on training and performance. In this case, attitude is also everything [5-7, 10, 11, 13, 21-23]. }\end{array}$ \\
\hline $\begin{array}{c}\text { Employee } \\
\text { Empowerment }\end{array}$ & $\begin{array}{l}\text { It is important that every member of an organisation can freely communicate or make } \\
\text { suggestions that they feel will increase the quality of a product. Employees should be given } \\
\text { autonomy. Suggestions made by employees will enable effective decision making [5-8, 10, } \\
11,13,21,23] \text {. }\end{array}$ \\
\hline $\begin{array}{c}\text { Employee } \\
\text { Commitment and } \\
\text { Attitude }\end{array}$ & $\begin{array}{l}\text { Low loyalty, little commitment from employees often affect the outcomes of software } \\
\text { development processes. Organisations should seek to reward employees for hard work while } \\
\text { employees should respond to these rewards by working hard to achieve a common goal } \\
\text { which is satisfying the client }[6-8,10,22] \text {. }\end{array}$ \\
\hline $\begin{array}{l}\text { Conti } \\
\text { Impro }\end{array}$ & $\begin{array}{l}\text { Continuous Improvement means to continuously improve the products and services to meet } \\
\text { clients' needs. It is also an essential factor in TQM philosophy. Hence, organisations are to } \\
\text { come up with long-term improvement strategies. Systematic measurement provides valuable } \\
\text { insights to improve software development processes. Feedbacks from clients have proved to } \\
\text { be a useful improvement strategy }[5,7,10] \text {. }\end{array}$ \\
\hline Benchmarking & $\begin{array}{l}\text { Benchmarking is very important for the implementation of TQM. Benchmarking is used to } \\
\text { compare various processes during software development and implementing the most efficient } \\
\text { processes. Quality standards such as PCMM, CMM and ISO need to be benchmarked by } \\
\text { companies or organisations }[5-7,13] \text {. }\end{array}$ \\
\hline $\begin{array}{l}\text { Infrastructure and } \\
\text { Facilities }\end{array}$ & $\begin{array}{l}\text { Besides good employees and high level of motivation, an excellent infrastructure like tools, } \\
\text { management technique, materials and methods are essential for the implementation of TQM. } \\
\text { Therefore, organisations are to follow the present technological advancement for adequate } \\
\text { progress in the software development sector for competitive advantage }[7,8] \text {. }\end{array}$ \\
\hline Risk Management & $\begin{array}{l}\text { Risk management is a management technique that aims to minimise the failures that may } \\
\text { occur due to unforeseen events. Therefore, it is crucial that employees be trained to resolve } \\
\text { challenges that may occur from unexpected risks. It is also vital to note that risks can cause } \\
\text { damage such as cost implications and human life }[7,10] \text {. }\end{array}$ \\
\hline Comm & 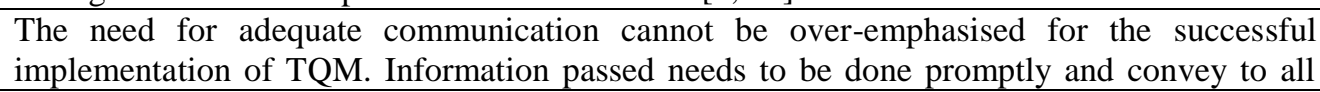 \\
\hline
\end{tabular}


Vol. 6, Issue 2, February 2019

\begin{tabular}{|c|c|}
\hline & $\begin{array}{l}\text { epartments that are involved. These information aid in decisions making processes thus } \\
\text { nproves quality of product or service. Communication gap is a major reason for TQM } \\
\text { ailure }[5-7,10,23] \text {. }\end{array}$ \\
\hline $\begin{array}{l}\text { Cycle time } \\
\text { reduction }\end{array}$ & $\begin{array}{l}\text { To improve the quality of software development, the cycle time reduction needs to be a } \\
\text { significant consideration. A reduction in cycle time assists organisations in decreasing } \\
\text { expenditure, resource wastage, Time-to-Market, increasing revenue, and improving } \\
\text { operational efficiency. Hence, organisations should adopt programs to reduce the cycle time } \\
\text { of development, delivery, and order-processing [11]. }\end{array}$ \\
\hline $\begin{array}{l}\text { Strategic } \\
\text { planning }\end{array}$ & $\begin{array}{l}\text { Strategic planning has always been a focal challenge for companies or organisations that } \\
\text { choose to adopt TQM. The organisation's vision, mission, policies, and, guidelines should be } \\
\text { affected by this transformation. Strategic planning helps organisations to imbibe a culture of } \\
\text { quality }[5,10,13,23] \text {. }\end{array}$ \\
\hline $\begin{array}{c}\text { Supplier } \\
\text { Management }\end{array}$ & $\begin{array}{l}\text { It is true that organisations are trying to cut down cost, but it should not be done at the } \\
\text { expense of quality. Therefore, quality suppliers need to be selected above price. A good } \\
\text { relationship with these suppliers needs to be built to create a long-term business relationship } \\
{[6,7,10,22] \text {. }}\end{array}$ \\
\hline Simp & $\begin{array}{l}\text { The aspect of simplicity is regarded as a factor for implementing TQM. Organisations stand } \\
\text { the chance of creating unnecessary risks that are related to business processes, and relational } \\
\text { database when complicated software is created and therefore re-engineering processes should } \\
\text { be carried out regularly. Simplicity must be considered form three aspects; they are code } \\
\text { simplicity, functional simplicity, and structural simplicity [21]. }\end{array}$ \\
\hline $\begin{array}{l}\text { Prototyping/evoluti } \\
\text { onary development }\end{array}$ & $\begin{array}{l}\text { Prototyping helps organisations to understand the customer's requirements. Therefore, it is a } \\
\text { factor for implementing TQM. Hence, it is advised to map out a plan which involves the } \\
\text { system architecture. This will help in software risk management and improve software } \\
\text { quality [21]. }\end{array}$ \\
\hline $\begin{array}{c}\text { The Role of Quality } \\
\text { Department }\end{array}$ & $\begin{array}{l}\text { Since quality is the primary focus of many organisations, quality check and control } \\
\text { departments exist in many of these organisations. It is also a prerequisite for the } \\
\text { implementation of TQM. Quality Department helps to check the processes and standards of } \\
\text { each phase of the products such that it forms a complete cooperative system [6]. }\end{array}$ \\
\hline $\begin{array}{l}\text { Product Design } \\
\text { Process }\end{array}$ & $\begin{array}{l}\text { The software design process demands specialists in many areas and that there is a general } \\
\text { knowledge across disciplines. Hence, it is essential that every department in the organisation } \\
\text { should participate in the design process to meet and satisfy customers' needs[6]. }\end{array}$ \\
\hline
\end{tabular}

Table 2 Comparative Studies Between Research Papers According to TQM Factors in Software Development

\begin{tabular}{|c|c|c|c|c|c|c|c|c|c|c|}
\hline Critical Factors & {$[13]$} & {$[23]$} & {$[22]$} & {$[11]$} & {$[6]$} & {$[10]$} & {$[8]$} & {$[7]$} & {$[21]$} & [5] \\
\hline $\begin{array}{c}\text { Top- } \\
\text { management } \\
\text { Commitment and } \\
\text { Leadership }\end{array}$ & $\sqrt{ }$ & $\sqrt{ }$ & $\sqrt{ }$ & $\sqrt{ }$ & $\sqrt{ }$ & $\sqrt{ }$ & $\sqrt{ }$ & $\sqrt{ }$ & $\sqrt{ }$ & $\sqrt{ }$ \\
\hline $\begin{array}{c}\text { Client } \backslash \text { Customer } \\
\text { Focus }\end{array}$ & & $\sqrt{ }$ & $\sqrt{ }$ & $\sqrt{ }$ & $\sqrt{ }$ & & $\sqrt{ }$ & $\sqrt{ }$ & $\sqrt{ }$ & $\sqrt{ }$ \\
\hline $\begin{array}{l}\text { Organizational } \\
\text { Culture }\end{array}$ & & & $\sqrt{ }$ & & & $\sqrt{ }$ & $\sqrt{ }$ & $\sqrt{ }$ & & \\
\hline $\begin{array}{l}\text { Process Quality } \\
\text { Management }\end{array}$ & $\sqrt{ }$ & $\sqrt{ }$ & $\sqrt{ }$ & $\sqrt{ }$ & $\sqrt{ }$ & $\sqrt{ }$ & & $\sqrt{ }$ & & $\sqrt{ }$ \\
\hline $\begin{array}{l}\text { Quality } \\
\text { Measures } \\
\text { (Metrics) }\end{array}$ & $\sqrt{ }$ & $\sqrt{ }$ & $\sqrt{ }$ & $\sqrt{ }$ & $\sqrt{ }$ & $\sqrt{ }$ & & $\sqrt{ }$ & & \\
\hline $\begin{array}{l}\text { Human Resource } \\
\text { Management }\end{array}$ & $\sqrt{ }$ & $\sqrt{ }$ & $\sqrt{ }$ & $\sqrt{ }$ & $\sqrt{ }$ & $\sqrt{ }$ & & $\sqrt{ }$ & $\sqrt{ }$ & $\sqrt{ }$ \\
\hline
\end{tabular}


International Advanced Research Journal in Science, Engineering and Technology

Vol. 6, Issue 2, February 2019

\begin{tabular}{|c|c|c|c|c|c|c|c|c|c|c|}
\hline $\begin{array}{c}\text { Employee } \\
\text { Empowerment }\end{array}$ & $\sqrt{ }$ & $\sqrt{ }$ & & $\sqrt{ }$ & $\sqrt{ }$ & $\sqrt{ }$ & $\sqrt{ }$ & $\sqrt{ }$ & $\sqrt{ }$ & $\sqrt{ }$ \\
\hline $\begin{array}{c}\text { Employee } \\
\text { Commitment and } \\
\text { Attitude }\end{array}$ & & & $\sqrt{ }$ & & $\sqrt{ }$ & $\sqrt{ }$ & $\sqrt{ }$ & $\sqrt{ }$ & & \\
\hline $\begin{array}{l}\text { Continuous } \\
\text { Improvement }\end{array}$ & & & & & & $\sqrt{ }$ & & $\sqrt{ }$ & & $\sqrt{ }$ \\
\hline Benchmarking & $\sqrt{ }$ & & & & $\sqrt{ }$ & & & $\sqrt{ }$ & & $\sqrt{ }$ \\
\hline $\begin{array}{l}\text { Infrastructure } \\
\text { and Facilities }\end{array}$ & & & & & & & $\sqrt{ }$ & $\sqrt{ }$ & & \\
\hline $\begin{array}{c}\text { Risk } \\
\text { Management }\end{array}$ & & & & & & $\sqrt{ }$ & & $\sqrt{ }$ & & \\
\hline Communication & & $\sqrt{ }$ & & & $\sqrt{ }$ & $\sqrt{ }$ & & $\sqrt{ }$ & & $\sqrt{ }$ \\
\hline $\begin{array}{l}\text { Cycle time } \\
\text { reduction }\end{array}$ & & & & $\sqrt{ }$ & & & & & & \\
\hline $\begin{array}{l}\text { Strategic quality } \\
\text { planning \ policy }\end{array}$ & $\sqrt{ }$ & $\sqrt{ }$ & & & & $\sqrt{ }$ & & & & $\sqrt{ }$ \\
\hline $\begin{array}{c}\text { Supplier } \\
\text { Management }\end{array}$ & & & $\sqrt{ }$ & & $\sqrt{ }$ & $\sqrt{ }$ & & & & $\sqrt{ }$ \\
\hline Simplicity & & & & & & & & & $\sqrt{ }$ & \\
\hline $\begin{array}{c}\text { Prototyping/evol } \\
\text { utionary } \\
\text { development }\end{array}$ & & & & & & & & & $\sqrt{ }$ & \\
\hline $\begin{array}{l}\text { The Role of } \\
\text { Quality } \\
\text { Department }\end{array}$ & & & & & $\sqrt{ }$ & & & & & \\
\hline
\end{tabular}

VII. RESULTS

Table 2 shows the results obtained from analyzing research papers according to TQM factors in software development. From this table, we can see that Top Management Commitment and Leadership remains one of the essential CSF over time and this result is in alignment with the most studies [24, 25].

That means there is still a significant positive correlation between Top-management Commitment and Leadership and TQM. The reason behind that is because Top-management Commitment and Leadership is represented as the bedblock that the pyramid structure of TQM implementation rests [26-28], as well as they, are mainly responsible for the quality as they have control over all decisions.

The second important CSF according to the frequency in table 2 was Human Resource Management and Employee Empowerment. A healthy relationship between TQM and Human Resource Management has been reported in many studies such as $[29,30]$. It seems possible that this result is because particular tacit would improve quality more than TGM tools and techniques [31]. In addition to that; Employee Empowerment was one of the second most crucial CSF as Human Resource Management. This result is likely to be related to the fact that when the employees have a certain amount of autonomy, this creates a positive impact on creativity and achievement which eventually increases the TQM [32].

The third important CSF for TQM was customer focus and process quality management. A possible explanation for this might be that focusing the requirements of customers and satisfying them increases TQM because in that case, the 


\title{
International Advanced Research Journal in Science, Engineering and Technology
}

\author{
Vol. 6, Issue 2, February 2019
}

software meets precisely what the customers expect it to do. Process quality management is also listed as the third essential CSF because improving the process continuously is the crucial factor that leads to improving the overall TQM through building the software in less time, with less effort and fewer defects.

On the other hand; there are many CSF that becomes less important now than before. These are including product design process, the role of the Quality Department, infrastructure and facilities, risk management, cycle time reduction, simplicity, and prototyping/evolutionary development. A possible primary reason for this might be because technology evolution has reshaped everything. The second reason behind that depends on many factors like the size of the organization as well as if the country is developing or developed country. In contrast to other criteria, however, some criteria only apply to the development processes which are simplicity, product design process, and cycle time reduction. If those criteria do not exist; the software will not be of high quality. The recent findings may help us to understand the impact of the progress in time and technology on the rank of the essential CSFs and discovering the new CSFs that did not exist before.

\section{CONCLUSION}

This research paper shows a holistic overview of the critical CSFs that are used to achieve TQM in software development. There is substantial proof that suggests CSFs are evolving with the technology over time, which reacted in the disappearing CSFs as well as the newly identified. This literature review has revealed that there are currently 20 CSFs in software development that contribute towards achieving TQM, as outlined in table 1 and 2. Of these 5 CSFs are recommended for use over all the time.

More research should be conducted to investigate if all those CSFs in software development will differ from country to country as well as if there is a relationship between the type of the countries, developed or developing and the ranking of those CSFs.

\section{REFERENCES}

[1] J. Carroll, "The application of total quality management to software development," Information Technology \& People, vol. 8, no. 4, pp. 35-47, 1995.

[2] S. Kan, V. R. Basili, and L. N. Shapiro, "Software quality: an overview from the perspective of total quality management," IBM Systems Journal, vol. 33, no. 1, pp. 4-19, 1994

[3] F. Redmill, "Considering quality in the management of software-based development projects," Information and Software Technology, vol. 32, no. 1 , pp. $18-22,1990$.

[4] A. C. Stylianou, R. L. Kumar, and M. J. Khouja, "A total quality management-based systems development process," ACM SIGMIS Database: the DATABASE for Advances in Information Systems, vol. 28, no. 3, pp. 59-71, 1997.

[5] E. Alhazmi, W. Bajunaid, and A. Aziz, "Important Success Aspects for Total Quality Management in Software Development," International Journal of Computers and Applications, vol. 157, no. 8, pp. 8-11, 2017.

[6] F. Dewhurst, A. R. Martínez Lorente, and B. G. Dale, "Total quality management and information technologies: an exploration of the issues," International Journal of Quality \& Reliability Management, vol. 16, no. 4, pp. 392-406, 1999.

[7] G. Issac, C. Rajendran, and R. Anantharaman, "A conceptual framework for total quality management in software organizations," Total Quality Management \& Business Excellence, vol. 15, no. 3, pp. 307-344, 2004.

[8] L. Y. Fok, W. M. Fok, and S. J. Hartman, "Exploring the relationship between total quality management and information systems development," Information \& Management, vol. 38, no. 6, pp. 355-371, 2001.

[9] S. Alamri and A.AbdulAziz, "The Effectiveness of Implementing Total Quality Management in Software Development," IARJSET, vol. 3, pp. 206-211, 2016.

[10] E. Y. Li, H.-G. Chen, and W. Cheung, "Total quality management in software development process," The Journal of Quality Assurance Institute, vol. 14, no. 1, pp. 4-6, 2000.

[11] M. J. Parzinger and R. Nath, "A study of the relationships between total quality management implementation factors and software quality," Total quality management, vol. 11, no. 3, pp. 353-371, 2000.

[12] J. M. Juran, "Mode in USA: A Renoissonce in Quality," Harvard business review, 1993.

[13] J. V. Saraph, P. G. Benson, and R. G. Schroeder, "An instrument for measuring the critical factors of quality management," Decision sciences, vol. 20, no. 4, pp. 810-829, 1989.

[14] G. S. Easton and S. L. Jarrell, "The effects of total quality management on corporate performance: an empirical investigation," The Journal of Business, vol. 71, no. 2, pp. 253-307, 1998.

[15] D. J. Lemak, R. Reed, and P. Satish, "Commitment to total quality management: is there a relationship with firm performance?," Journal of Quality Management, vol. 2, no. 1, pp. 67-86, 1997.

[16] B. B. Flynn, R. Schroeder, and S. Sakakibara, "Determinants of quality performance in high-and low-quality plants," Quality Management Journal, vol. 2, no. 2, pp. 8-25, 1995.

[17] D. Ittner and F. Larcker, "Measuring the Impact of Quality Initiatives on Firm Financial Performance," Advances in the management of Organizational Quality, 1996.

[18] K. B. Hendricks and V. R. Singhal, "The long-run stock price performance of firms with effective TQM programs," Management Science, vol. 47, no. 3, pp. 359-368, 2001.

[19] D. I. Prajogo and A. S. Sohal, "TQM and innovation: a literature review and research framework," Technovation, vol. 21, no. 9, pp. 539-558, 2001.

[20] W. F. Foster, "TQM for Information Systems Management: Quality Practices for Continuous Improvement," Quality Progress, vol. 29, no. 5, p. $164,1996$. 


\title{
International Advanced Research Journal in Science, Engineering and Technology
}

\author{
Vol. 6, Issue 2, February 2019
}

[21] G. H. Subramanian, J. J. Jiang, and G. Klein, "Software quality and IS project performance improvements from software development process maturity and IS implementation strategies," Journal of Systems and Software, vol. 80, no. 4, pp. 616-627, 2007.

[22] K. Padhy, "Total quality management: An overview," Srusti Management Review, vol. 6, no. 1, p. 119, 2013.

[23] L. J. Porter and A. J. Parker, "Total quality management-the critical success factors," Total quality management, vol. 4, no. 1, pp. 13-22, 1993.

[24] V. A. Zeithaml, L. L. Berry, and A. Parasuraman, "The behavioral consequences of service quality," the Journal of Marketing, pp. 31-46, 1996.

[25] P. Jalote, CMM in practice: processes for executing software projects at Infosys. Addison-Wesley Professional, 2000

[26] G. K. Kanji, "Implementation and pitfalls of total quality management," Total Quality Management, vol. 7, no. 3, pp. 331-343, 1996.

[27] G. K. Kanji and M. Asher, 100 methods for total quality management. Sage, 1996.

[28] K. Kanji and M. Asher, "Total quality management process: a systematic approach," Carfax, 1993.

[29] M. Vijayabaskar, S. Rothboeck, and G. V, "Labour in the new economy: Case of the Indian Software industry," The Indian Journal of Labour Economics, vol. 44, no. 1, pp. 39-54, 2001.

[30] R. Heeks, India's software industry: State policy, liberalisation and industrial development. Sage Publications, Inc., 1996.

[31] T. C. Powell, "Total quality management as competitive advantage: a review and empirical study," Strategic management journal, vol. 16, no. 1, pp. 15-37, 1995.

[32] M. Santana and D. Robey, "Perceptions of control during systems development: Effects on job satisfaction of systems professionals," ACM SIGCPR Computer Personnel, vol. 16, no. 1, pp. 20-34, 1995. 